\title{
Study on the Performance Characteristics of Sequencing Batch Membrane Bioreactor for Distributed Treatment of Domestic Wastewater
}

\author{
Gong Cheng ${ }^{1}$, Amarendra Dhar Dwivedi², Jie Fu³ \\ 1 Shenzhen Academy of Environmental Sciences, Shenzhen 518001, China \\ 2 Department of Chemistry, Y.N. College (J.P. University), Chapra, Bihar, India \\ ${ }^{3}$ Department of Environmental Science \& Engineering, Fudan University, Shanghai 200433, China \\ * Corresponding author, email: jiefu@fudan.edu.cn
}

Received: 04 March 2018, Accepted: 03 May 2018, Published online: 04 May 2018

\begin{abstract}
A large amount of domestic wastewater is produced in our daily life. To sustainably use the urban domestic wastewater in the residential area and develop the equipment for distributed domestic wastewater treatment, the present work carried out a pilot study on the treatment of domestic wastewater by sequencing batch membrane bioreactor (SBMBR). Under the conditions of $20 \mathrm{~L} / \mathrm{h} \cdot \mathrm{m}^{2}$ of average water flux, and $2 \mathrm{~h} / 3 \mathrm{~h}$ of anaerobic/aerobic period, the SBMBR process showed a good treatment effect with a good quality of effluent ( $<50 \mathrm{mg} / \mathrm{L}$ of chemical oxygen demand (COD), $<5 \mathrm{mg} / \mathrm{L}$ of ammonia nitrogen $\left(\mathrm{NH}_{3}-\mathrm{N}\right),<15 \mathrm{mg} / \mathrm{L}$ of total nitrogen (TN), $<2.6$ NTU of turbidity, $96.9 \%$ of color removal and $99.9 \%$ of bacteria removal). The aeration quantity had a certain degree of impact on the removal of COD and the optimum aeration rate was $13.9 \mathrm{~m}^{3} / \mathrm{m}^{3} \cdot \mathrm{h}$ considering both the effectiveness and cost. When the SBMBR was continuously operated for 40 days, the transmembrane pressure reached $50 \mathrm{kPa}$ and the membrane needed to clean. The hydrochloric acid $(\mathrm{pH} \approx 2$ ) was a suitable cleaning agent and the membrane was almost completely restored after cleaning.

Keywords
\end{abstract}

sequencing batch membrane bioreactor, domestic wastewater, aeration quantity, membrane cleaning

\section{Introduction}

Water recycling and reuse is an effective measure to solve the shortage problem of water resource, and the sustainable use of water resource has become a national development strategy in China. Currently, $80 \%$ of urban water supply has been discharged into the sewer as domestic wastewater, which is an available and promising freshwater resource [1]. Reclaimed water has the widespread use such as agricultural land irrigation, aquaculture, landscape irrigation, urban and industrial applications, artificial recharging of groundwater, and even providing potable water [2,3]. Current technologies applied in water reclamation include oxidation-chlorination by sodium hypochlorite $(\mathrm{NaClO})$, ultraviolet (UV) irradiation and ozonation, biological treatments such as aerobic/anaerobic bioreactors, maturation ponds and constructed wetlands, physical separations such as medium filtration and membrane filtration, and electrochemical treatments [4]. Of these available technologies, membrane bioreactor (MBR) technology has been proposed as being highly suitable for water reclamation [5]. The MBR is a technology of wastewater treatment in a combination with membrane separation and biotreatment [6]. In the MBR system, almost all solids and microorganisms will be intercepted by the membrane, and the attached activated sludge has a strong ability in removing organic matters via (bio)sorption/ biodegradation [3]. The MBR is characterized by good effluent quality, simple operation, compact structure, and small land occupation, revealing very broad application prospects in the area of wastewater recycling and reuse.

MBR is composed of membranes (such as microfiltration membrane, ultrafiltration membrane or nanofiltration membrane) and a bioreactor. According to the different functions of membranes, MBR can be categorized as separate, aerated and extractive MBRs. In terms of configuration, MBR membranes can be divided into the types of branched passage, frame plate, and rolling and hollow fibers. Moreover, for the materials, MBR membranes have organic and inorganic types. According to the assembly 
position of membrane and bioreactor, MBR can be divided into the integrated model (immersion) and split model (circulation). On the basis of the driving mode in membrane filtration, MBRs have pressure mode and suction mode [7-10]. The MBR has a high biological sludge concentration and extended sludge retention time (SRT), making it effective to remove ammonia nitrogen $\left(\mathrm{NH}_{3}-\mathrm{N}\right)$ and chemical oxygen demand (COD), and also very effective to treat wastewater with low-degradable substances. MBR technology has gradually been applied for the treatment of domestic and industrial wastewaters in recent years [11]. It replaces the separation unit of the conventional activated sludge method with the membrane separation system, and thus simplifies the process, improves the effects of liquid-solid separation and obtains quality effluent for direct recycling use, such as agricultural and landscape irrigation, industrial processes and toilet flushing. The removal of organic substances by MBR is mainly attributed to the membranes interception and biodegradation by microorganisms in the activated sludge and/or attached to the membrane surface. The activated sludge in the MBR can remove $>60 \%$ COD of the influent wastewater due to the high concentration of microorganisms and relatively long SRT. On the other hand, the membrane compensates for the instability of biological treatment by efficiently intercepting organic macromolecules (e.g., soluble microbial metabolites) and ensures the good quality of the effluent. Various researches and cases have demonstrated that the effluent of MBR does not contain solids and macromolecular colloids. The MBR is fully capable of retaining suspended substances and producing water with nearly zero turbidity. Therefore, the effluent quality of MBR meets the requirements of reclaimed water for multipurpose [12-16].

Along with the increasingly mature application of MBR technology in wastewater treatment, there has been a phenomenal development in the research on the removal of the nitrogen and phosphorus by MBR. Currently, most MBR technologies for nitrogen and phosphorus removal are developed based on the traditional mechanism of nitrification/denitrification and aerobic excessive phosphorus absorption/anaerobic phosphorus release [17]. According to the space and time for the removal of nitrogen and phosphorus, MBRs have two modes, i.e., two-stage spatial separation and integrated temporal separation. Compared with the conventional MBRs, the sequencing batch membrane bioreactor (SBMBR) greatly enhances the removal of nitrogen and phosphorus [18]. It forms the alternate anoxic/aerobic conditions by intermittent aeration in a single reactor and achieves synchronous removal of carbon, nitrogen and phosphorus. This technology is featured by mixed reaction in terms of space and flow reaction in terms of time [18].

Nowadays, affected by the global sustainable development strategies, people began to rethink the conception and philosophy of centralized sewage treatment advocated by water experts. Looking back on the development course of sewage treatment in the 20th century, we have found that centralized sewage treatment has obvious historical limitations, when we consider the reuse of sewage in the water shortage today. Centralized sewage treatment with great energy and expense cannot solve problems of environmental pollution, water shortage and drinking water safety. The technical progress, social development and environmental changes have driven the appearance of new philosophical thinking on sewage treatment; that is the idea of distributed sewage treatment, local treatment and reuse of wastewater to achieve water balance. Currently, many water scientists are actively promoting such idea. Considering the national conditions, distributed sewage treatment is very suitable in China. Especially for the residential area, the local collection, treatment and recycling of wastewater is more economic and feasible than centralized treatment [1].

To evaluate the feasibility and robustness of SBMBR on water reclamation as a smaller distributed sewage treatment technology/equipment, the present research has designed a small-scale SBMBR to carry out a pilot study on treatment of domestic wastewater. The characteristics of pollutants removal by SBMBR were comprehensively studied. The influence of aeration quantity, and the membrane fouling and cleaning were also investigated. The objective is to optimize the parameters and accumulate the data and experience for the application of such process in the distributed sewage treatment.

\section{Materials and methods}

\subsection{Experimental equipment}

The SBMBR experimental equipment of this pilot study is shown in the Fig. 1. The equipment ran automatically through the control with a programmable logic controller (PLC) (5). An operating cycle needed $\sim 6 \mathrm{~h}$ and the hydraulic retention time (HRT) was $4 \mathrm{~h}$. Firstly, the intake pump (4) pumped the sewage from the sewage storage tank (1) to the reactor (2) to the maximum water level $\left(\mathrm{H}_{\max }\right)$. The sewage was then stirred by the mixing pump (6) for a 2-h of anaerobic reaction. After that the mixing pump (6) was stopped and the solenoid valve (8) was opened to start the aerobic aeration. Two hours later, the outlet pump (9) 


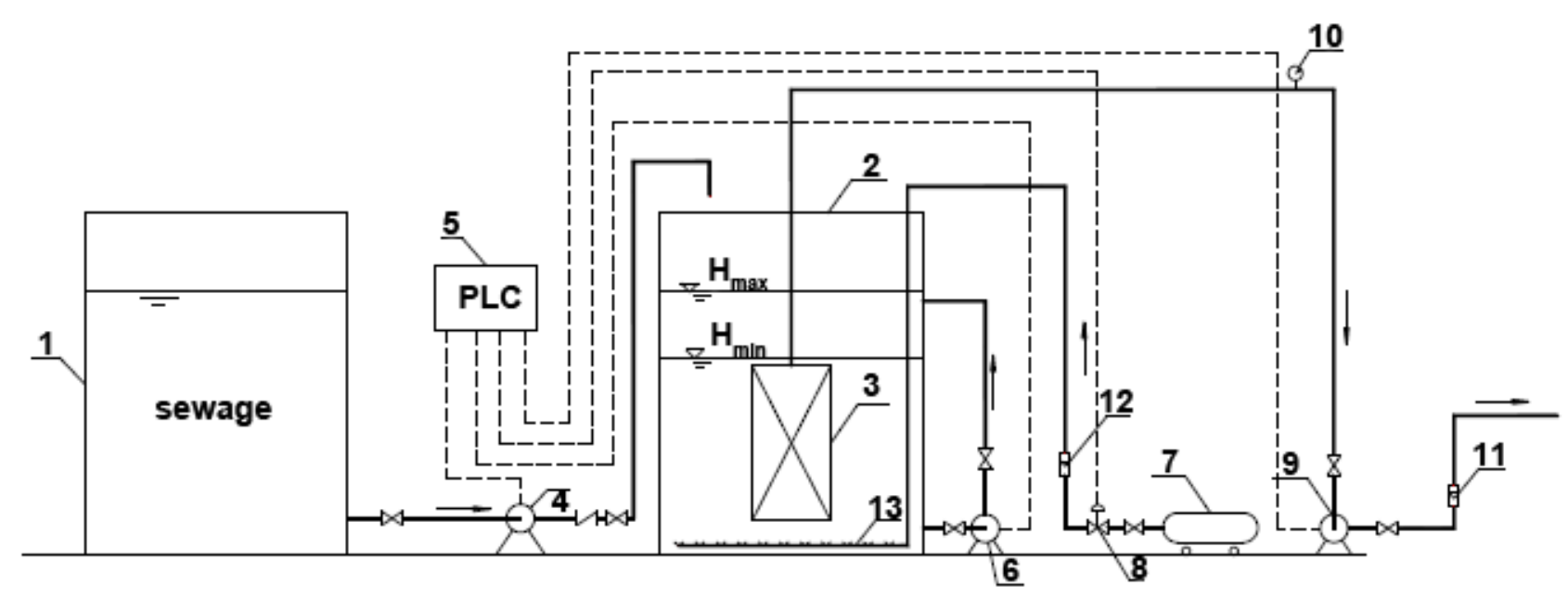

Fig. 1 Schematics of the equipment set-up of the SBMBR: 1 sewage storage tank, 2 reactor, 3 membrane, 4 intake pump, 5 PLC (programmable logic controller), 6 mixing pump, 7 air compressor, 8, solenoid valve, 9 outtake pump, 10 vacuum meter, 11 effluent flow meter, 12 intake air flow meter, and 13 perforated aeration tube.

was opened to discharge the effluent until the water level reached the minimum value $\left(\mathrm{H}_{\min }\right)$ at an average flux of $20 \mathrm{~L} / \mathrm{m}^{2} \cdot \mathrm{h}$, which was achieved by resting the pump (9) for $3 \mathrm{~min}$ after every $10 \mathrm{~min}$ working. Afterwards, the intake pump (4) was started and the system entered the next operation cycle.

The SBMBR reactor (2) was made of plexiglass with an effective volume of $60 \mathrm{~L}$. The effective membrane area of membrane module (3) was $1 \mathrm{~m}^{2}$, which was adopted the polyvinylidene difluoride (PVDF) hollow fiber (DD WATER Group Co. Ltd, Zhuji, China). Table 1 shows the parameters of the fiber membrane. The aerated air was proved by an air compressor (7) (Jaguar, Xiamen, China) and a flow meter (12) was used to monitor the intake air flow. Perforated aeration pipes (13) (Tiancheng Environmental Equipment Co. Ltd, Yixing, China) were installed at the bottom of the reactor. The proportion of air to water was controlled at around 10:1, and the ratio of reactor water filling was about 3:10.

\subsection{Test sewage and analysis}

The test sewage was the inflow of regulating reservoir of a sewage treatment station. The parameters of the test sewage are shown in Table 2. The determinations of water quality indices such as $\mathrm{COD}$, total nitrogen (TN), $\mathrm{NH}_{3}-\mathrm{N}$, total phosphorus (TP), and chroma were according to the standard methods [19]. The total number of bacteria was determined using the dilution spread plate method. The odor threshold was measured by the standard method [20]. The turbidity was determined with a HACH2100AN turbidimeter (Hach, Loveland, USA).
Table 1 Parameters of the PVDF hollow fiber membrane

\begin{tabular}{|c|c|c|c|}
\hline Surface area $\left(\mathrm{m}^{2}\right)$ & 0.25 & $\begin{array}{l}\text { Maximum suction negative } \\
\text { pressure }(\mathrm{MPa})\end{array}$ & 0.05 \\
\hline Pore size $(\mu \mathrm{m})$ & 0.1 & Tolerant $\mathrm{pH}$ range & $2-12$ \\
\hline $\begin{array}{l}\text { Inner diameter } \\
(\mathrm{mm})\end{array}$ & 1 & $\begin{array}{l}\text { Tolerant temperature range } \\
\left({ }^{\circ} \mathrm{C}\right)\end{array}$ & $15-35$ \\
\hline $\begin{array}{l}\text { External diameter } \\
(\mathrm{mm})\end{array}$ & 2 & $\begin{array}{l}\text { Maximum suction negative } \\
\text { pressure }(\mathrm{MPa})\end{array}$ & 0.05 \\
\hline
\end{tabular}

Table 2 Parameters of the test sewage

\begin{tabular}{lcll}
\hline $\begin{array}{l}\text { Water quality } \\
\text { index }\end{array}$ & Range & Water quality index & Range \\
\hline $\mathrm{COD}(\mathrm{mg} / \mathrm{L})$ & $67-284$ & $\mathrm{~T}\left({ }^{\circ} \mathrm{C}\right)$ & $11.2-30.6$ \\
$\mathrm{NH}_{3}-\mathrm{N}(\mathrm{mg} / \mathrm{L})$ & $10.3-22.4$ & Turbidity $(\mathrm{NTU})$ & $67-340$ \\
$\mathrm{TN}(\mathrm{mg} / \mathrm{L})$ & $20.8-29.2$ & Chroma & $150-250$ \\
$\mathrm{TP}(\mathrm{mg} / \mathrm{L})$ & $1.9-3.4$ & Odor threshold & $20-160$ \\
$\mathrm{pH}$ & $6.4-7.9$ & $\begin{array}{l}\text { Total number of } \\
\text { bacteria }(\mathrm{cfu} / \mathrm{L})\end{array}$ & $(1.5-2.9) \times 10^{6}$ \\
\hline
\end{tabular}

\subsection{Process parameters}

\subsubsection{Filtration flux}

The constant flux filtration is relative to the constant pressure filtration. Researches have shown that with the same pressure and flux, the constant flux filtration has less head loss than the constant pressure filtration [21]. During constant pressure filtration, the flux returns back to the stable level down from the supercritical level, when the particles in the main feed liquid move toward the membrane surface that incurs serious membrane fouling. However, the constant flux filtration is operating under the constant subcritical flux, which can avoid congesting the membrane pores. Therefore, the constant flux filtration can not only 
effectively control membrane fouling, extend the membrane cleaning cycles, maintain a high level of membrane flux and increase the operational stability, but also realize the balance of MBR water balance, keep the value of HRT constant, and reduce the impact of feed water on microorganisms. Therefore, the present study adopted the constant flux method and kept the membrane flux at $20-25 \mathrm{~L} \mathrm{~m}^{2} \cdot \mathrm{h}$ during operation.

\subsubsection{Aeration quantity}

To vibrate the membrane to alleviate the membrane fouling caused by clogging and the formation of the filter cake layer, air was inflated all the time in the membrane area, keeping the ratio of air to water at 10:1. The aeration can achieve the following functions. One was to maintain a certain concentration of dissolved oxygen in the reactor to provide the necessary oxygen for microbiological degradation and cell synthesis and other activities. The second function was to play the role of mixing and keep the activated sludge in suspension in the reactor for full contact with sewage. The third function was to wash against the membrane surface, reduce the membrane fouling and maintain the normal membrane flux. The aeration method and intensity have a direct influence on membrane fouling. The crossflow caused by aeration can effectively remove or reduce the gel layer fouling on the membrane surface.

\subsubsection{Reaction time}

The anaerobic reaction time was $2 \mathrm{~h}$ and aerobic reaction time (including water discharge time) was $3 \mathrm{~h}$.

\subsection{Cultivation and acclimation of activated sludge}

The inoculated sludge was obtained from the activated sludge in the concentrated tank of the sewage treatment station. The physicochemical properties of the inoculated sludge were as follows: organic carbon, $180.7 \mathrm{~g} / \mathrm{kg}$; total nitrogen, $15.5 \mathrm{~g} / \mathrm{kg}$; water content, $70.3 \%$; $\mathrm{pH}$ 7.0. The cultivation and acclimation of the activated sludge were conducted by continuous inletting and outletting water with an HRT of $4 \mathrm{~h}$ and an air-water ratio of 10:1. After $20 \mathrm{~d}$, the concentration of activated sludge in the reactor was $3300 \mathrm{mg} / \mathrm{L}$. The flocculent structure of sludge increased remarkably and the color turned taupe (from black before acclimation). A certain amount of protozoa such as vorticella and rotifers were observed under the microscopic investigation. It was then considered that the cultivation and acclimation of sludge had been completed and the experimental stage could be started.

\section{Results and discussion}

\subsection{Effect on water quality}

The SBMBR was continuously operated and the effect on water quality is shown in Fig. 2. According to Fig. 2a, the influent COD fluctuated obviously $(67-284 \mathrm{mg} / \mathrm{L})$. In the initial stage (1-6 d), the effluent COD was at $<90 \mathrm{mg} / \mathrm{L}$ while the values markedly fluctuated. In the late experimental stage (7-16 d), the effluent COD was stable at $<50 \mathrm{mg} / \mathrm{L}$, indicating the notable shock load capability of SBMBR. The effluent COD showed relatively huge fluctuations at a high level in the initial stage, which may be due to two reasons. On one hand, the fluctuation of initial influent COD would affect the COD removal effect. On one other hand, the activated sludge concentration was relatively low at the level of only $3000 \mathrm{mg} / \mathrm{L}$ in the initial stage and thus the microorganism amount was small. Therefore, the removal efficiency of COD by microorganisms was not satisfactory. But as the experiment went on, the activated sludge concentration in the reactor increased to the level of $6000 \mathrm{mg} / \mathrm{L}$ in the late stage, when the COD removal became very stable, and the effluent COD was kept at $<50 \mathrm{mg} / \mathrm{L}$ with a stable removal percentage of $\sim 75 \%$.

The influent $\mathrm{NH}_{3}-\mathrm{N}$ was ranged within $10.3-22.1 \mathrm{mg} / \mathrm{L}$ (Fig. 2b). During the experiment, the $\mathrm{NH}_{3}-\mathrm{N}$ removal effect improved gradually and the effluent $\mathrm{NH}_{3}-\mathrm{N}$ became more and more stable. The $\mathrm{NH}_{3}-\mathrm{N}$ removal effect was also poor in the initial stage (1-6 d), when the effluent $\mathrm{NH}_{3}-\mathrm{N}$ was $10.1-15.6 \mathrm{mg} / \mathrm{L}$ and removal percentage was 20.9 $47.5 \%$. The removal effect gradually improved during the mid-stage (7-12 d), with an effluent $\mathrm{NH}_{3}-\mathrm{N}$ of 6.3-10.7 $\mathrm{mg} / \mathrm{L}$ and removal percentage of $38.8-71.3 \%$. During the late stage (13-16 d), the SBMBR showed a good $\mathrm{NH}_{3}-\mathrm{N}$ removal effect with $<5 \mathrm{mg} / \mathrm{L}$ of effluent $\mathrm{NH}_{3}-\mathrm{N}$ and 65.4 $76.1 \%$ of removal percentage. By comparing Fig. $2 \mathrm{a}$ to $2 \mathrm{~b}$, it can be seen that more time was needed for $\mathrm{NH}_{3}-\mathrm{N}$ removal to become stable than for COD removal. The former took 12 days, while the latter took 6 days. This is because that the nitrobacteria have a long generation interval (generally 12-15 days), and need a longer time to reproduce and accumulate in the activated sludge system [22].

From Fig. 2c we can see that the influent TN is between 21.3 to $29.2 \mathrm{mg} / \mathrm{L}$ and the effluent TN is between 8.8 to $17.9 \mathrm{mg} / \mathrm{L}$ with a removal percentage of $17.4-63.4 \%$. In the initial stage, the reactor had an unobvious TN removal, which was possibly due to the long generation interval of nitrifying/denitrifying bacteria and the relatively long period to accumulate and enrich bacteria. The traditional theory indicates that the $\mathrm{TN}$ removal is completed through 


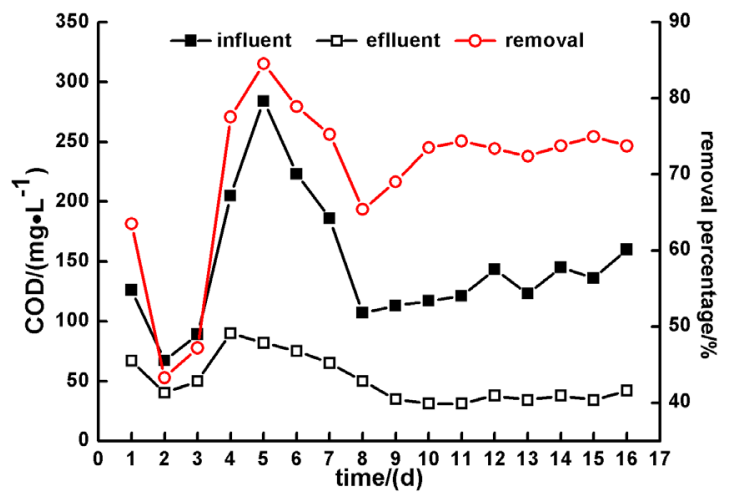

(a)

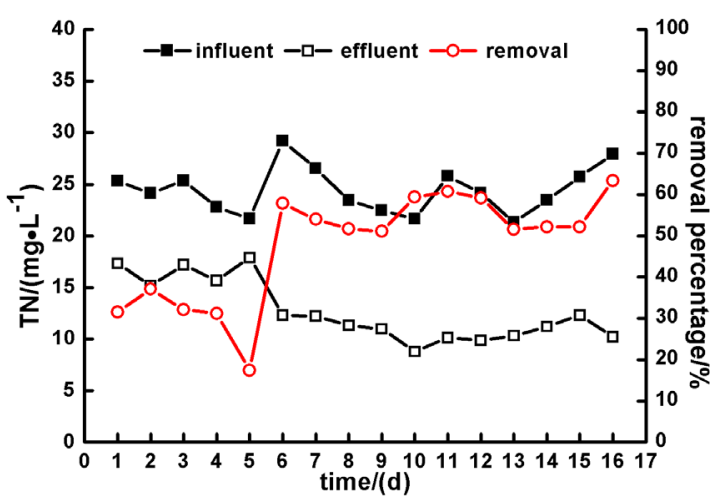

(c)

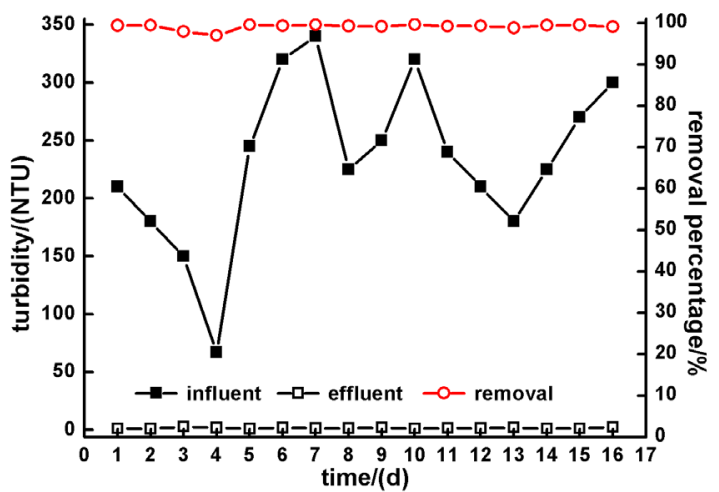

(e)

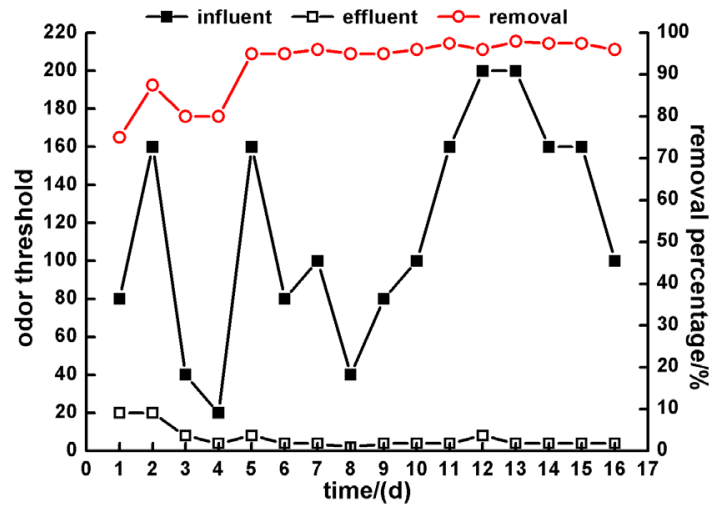

(g)

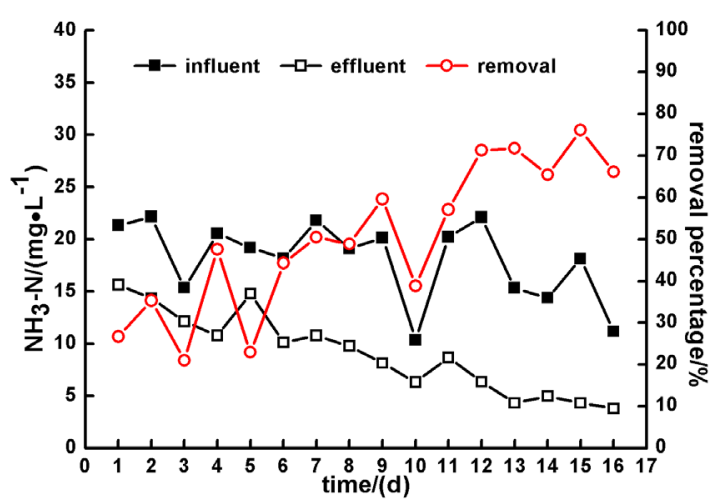

(b)

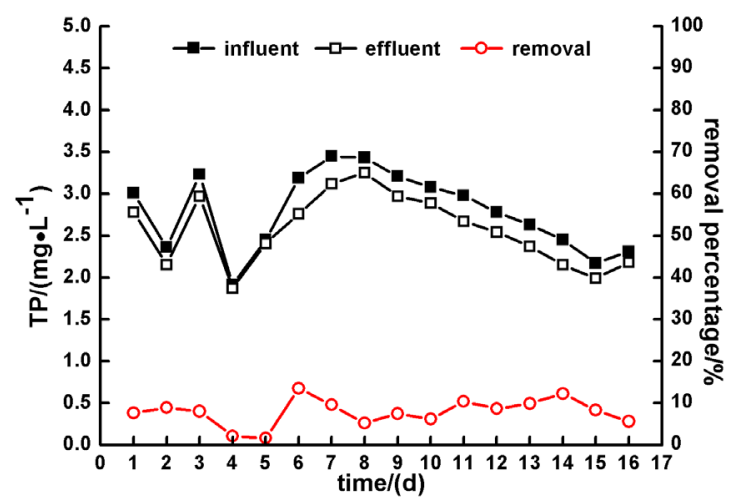

(d)

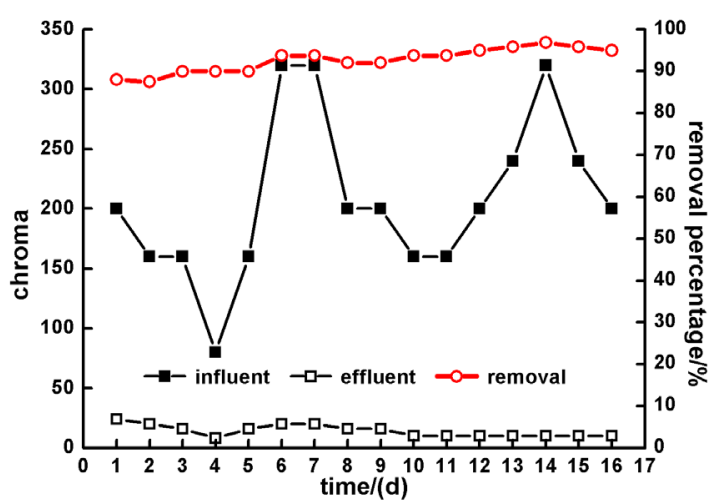

(f)

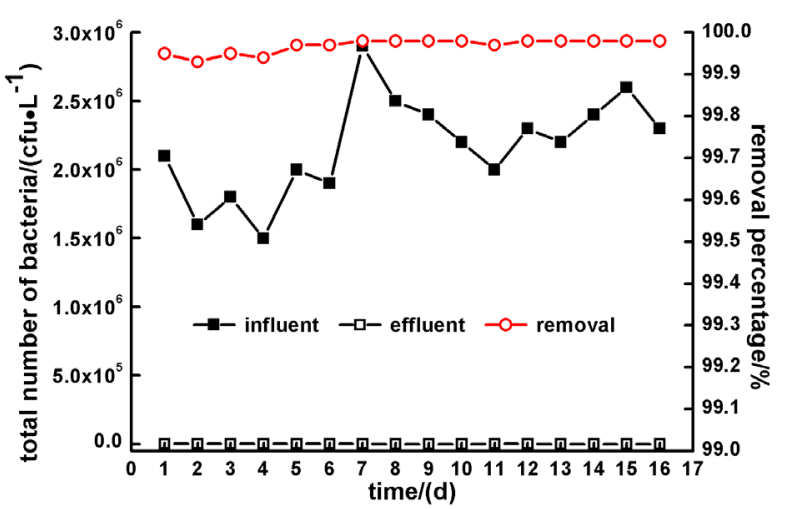

(h)

Fig. 2 SBMBR system treatment effect on water quality: (a) COD removal, (b) $\mathrm{NH}_{3}-\mathrm{N}$ removal, (c) TN removal, (d) TP removal, (e) turbidity removal, (f) chroma removal, (g) odor removal and (h) bacteria removal. 
two processes, i.e., the aerobic nitrifying process and the anoxic denitrifying process [23]. In the nitrifying process, oxygen acts as the electron acceptor, and the $\mathrm{NH}_{3}-\mathrm{N}$ is converted to nitrate and nitrite nitrogen by the nitrifying bacteria. After the aerobic nitrification, the nitrified liquid is processed by denitrifying bacteria under anoxic environments, taking organic matters as the electron acceptor, and regenerated the nitrogen from nitrate nitrogen. It is thus obvious that if the TN should be removed, both nitrifying and denitrifying bacteria must be formed an effective cluster to enable the biosystem to complete the nitrogen removal process. In the late stage, the $\mathrm{TN}$ removal effect was improved, implying that after a certain period, SBMBR had already formed an effective nitrifying and denitrifying microbiota.

Fig. $2 \mathrm{~d}$ shows that the influent TP is within $1.9-3.4 \mathrm{mg} / \mathrm{L}$ and the effluent TP is within 1.9-3.2 $\mathrm{mg} / \mathrm{L}$ with a removal percentage of $1.6-13.4 \%$. The removal percentage of TP was very low, indicating that the reactor had a limited effect on TP removal. The small amount of TP removal was mainly resulted from the effect of microbial assimilation. Generally, after the excessive phosphorus intake in aerobic condition and the phosphorus release in anaerobic condition by phosphorus-accumulating organisms, TP is removed along with discharging the remaining sludge [24]. However, no residues were discharged in this experiment. Due to the highly efficient intercepting effect of the membrane, most microorganisms were all retained in the reactor, thus resulting in the unobvious effect of TP removal.

Despite the huge fluctuation of influent turbidity (67340 NTU), the effluent turbidity remained basically at the same level below 2.6 NTU (Fig. 2e). The system showed a relatively high turbidity removal percentage and produced a more stable quality effluent which did not contain suspended particles, demonstrating the superior shock load capability of MBR. This is because the microfiltration membrane had smaller pore sizes and could sufficiently intercept suspended particles.

We can see from Fig. $2 \mathrm{f}$ that though the influent chroma fluctuated to some extent, the chroma removal percentage increased gradually from the initial $88 \%$ to $96.8 \%$ as the system operated on. The removal percentage of chroma constantly remained at a relatively high level, and it mainly relied on the efficient interception of suspended particles which may influence the chroma. As the times went on, the concentration of activated sludge in the reactor increased. Therefore, more and more microorganisms attached to the membrane surface to degrade the organic substances that may influence chroma, and it thus further promoted the removal of chroma.

Odorants include sulfur derived volatile organic compounds (VOCs) [25]. Although their concentrations are usually low and environment impacts are relatively small, the bad odor makes the water disgusting and affects its use. Biotechnologies such as MBR are recognized as the best available technologies for odor treatment due to the operational cost consideration [26]. Our results showed that SBMBR could efficiently remove the influent odor. After a short adaptive phase (1-4 d) due to the insufficient activated sludge, the average odor removal percentage was kept stable at $>95 \%$ (Fig. $2 \mathrm{~g}$ ).

Fig. $2 \mathrm{~h}$ shows that the total number of bacteria in influent fluctuated but the bacteria number in effluent remained stable at $<1 \times 10^{3} \mathrm{cfu} / \mathrm{L}$ with the removal percentage of over $99.9 \%$. Thus the effluent quality was relatively stable. This indicated that the membrane with $0.1 \mu \mathrm{m}$ pore size could efficiently intercept microorganisms. Generally, the typical size of bacteria is $0.2-1.2 \mu \mathrm{m}$ in diameter and 0.5 $5.0 \mu \mathrm{m}$ in length that is larger than the pore sizes of the membrane. Therefore, size exclusion by the membrane was probably the dominant mechanism for removing bacteria in SBMBR [27].

The test sewage in the present study is similar with that of previous study on sequencing batch biofilm reactor (SBBR) [1]. Thus, the treatment effects of the two technologies are compared (as in Table 3). The removal of nitrogen $\left(\mathrm{NH}_{3}-\mathrm{N}\right.$ and $\left.\mathrm{TN}\right)$ was comparable in SBMBR and SBBR. SBBR showed higher efficiency in removal of COD and TP compared with SBMBR. However, SBMBR had an excellent capacity to decrease the turbidity. Thus, MBR can be used as a subsequent procedure to remove the relatively high concentration of suspended solids in the effluent of SBBR.

Table 3 Comparison of effluent quality and treatment efficiency of SBMBR and SBBR

\begin{tabular}{lcccc}
\hline & \multicolumn{2}{c}{ SBMBR } & \multicolumn{2}{c}{ SBBR $^{\text {a }}$} \\
\cline { 2 - 5 } & Mean value & $\begin{array}{c}\text { Mean } \\
\text { removal }\end{array}$ & Mean value & $\begin{array}{c}\text { Mean } \\
\text { removal }\end{array}$ \\
\hline $\mathrm{COD}$ & $50.1 \mathrm{mg} / \mathrm{L}$ & $70.0 \%$ & $26.2 \mathrm{mg} / \mathrm{L}$ & $82.8 \%$ \\
$\mathrm{NH}_{3}-\mathrm{N}$ & $9.1 \mathrm{mg} / \mathrm{L}$ & $50.2 \%$ & $7.5 \mathrm{mg} / \mathrm{L}$ & $64.7 \%$ \\
$\mathrm{TN}$ & $12.7 \mathrm{mg} / \mathrm{L}$ & $47.7 \%$ & $12.4 \mathrm{mg} / \mathrm{L}$ & $58.4 \%$ \\
$\mathrm{TP}$ & $2.6 \mathrm{mg} / \mathrm{L}$ & $7.8 \%$ & $1.8 \mathrm{mg} / \mathrm{L}$ & $24.0 \%$ \\
Turbidity & $1.7 \mathrm{NTU}$ & $99.1 \%$ & $28.7 \mathrm{NTU}$ & $61.2 \%$ \\
\hline
\end{tabular}

${ }^{a}$ data are from the previous publication [1]. 
Compared with the quality standard for reclaimed water in China (GB 18918-2002), except TP, all the water quality indices of the effluents from SBMBR meet the requirements for standard A (Table 4). This indicates the effluents from SBMBR can be used as reclaimed water for multipurpose such as industrial water consumption, urban miscellaneous water consumption, and scenic environment use after appropriately reducing the TP level.

\subsection{Influence of aeration quantity}

Aeration is important for the MBR, which not only provides oxygen to the microbial community, but also maintains the activated sludge in suspension and vibrates the membrane surface to alleviate membrane fouling. Sufficient aeration is beneficial for the performance enhancement of MBR, however, it has been found that $>80 \%$ energy consumption is for aeration [28]. Therefore, determining the appropriate aeration quantity is necessary for the operation of MBR. Here, we used the influence on COD removal to

Table 4 Comparison of effluent quality of SBMBR and quality standard for reclaimed water

\begin{tabular}{lccc}
\hline & SBMBR & Standard A $^{\mathrm{a}}$ & Standard B $^{\mathrm{b}}$ \\
\hline $\mathrm{COD}$ & $50 \pm 19 \mathrm{mg} / \mathrm{L}$ & $50 \mathrm{mg} / \mathrm{L}$ & $60 \mathrm{mg} / \mathrm{L}$ \\
$\mathrm{NH}_{3}-\mathrm{N}$ & $9 \pm 4 \mathrm{mg} / \mathrm{L}$ & $8 \mathrm{mg} / \mathrm{L}$ & $15 \mathrm{mg} / \mathrm{L}$ \\
$\mathrm{TN}$ & $13 \pm 3 \mathrm{mg} / \mathrm{L}$ & $15 \mathrm{mg} / \mathrm{L}$ & $20 \mathrm{mg} / \mathrm{L}$ \\
$\mathrm{TP}$ & $2.6 \pm 0.4 \mathrm{mg} / \mathrm{L}$ & $0.5 \mathrm{mg} / \mathrm{L}$ & $1 \mathrm{mg} / \mathrm{L}$ \\
Turbidity & $2 \pm 1 \mathrm{NTU}$ & $5 \mathrm{NTU}$ & $10 \mathrm{NTU}$ \\
Chroma & $14 \pm 5$ & 30 & 30 \\
Odor & $7 \pm 6$ & $\backslash$ & $\backslash$ \\
threshold & & & $1 \times 10^{3} \mathrm{cfu} / \mathrm{L}$ \\
Total bacteria & $(0.7 \pm 0.2) \times 10^{3} \mathrm{cfu} / \mathrm{L}$ & $10 \times 10^{3} \mathrm{cfu} / \mathrm{L}$ \\
\hline
\end{tabular}

${ }^{a}$ reclaimed water for industrial water consumption, urban miscellaneous water consumption, and scenic environment use. ${ }^{\mathrm{b}}$ reclaimed water for urban afforestation and partial industrial water consumptions.

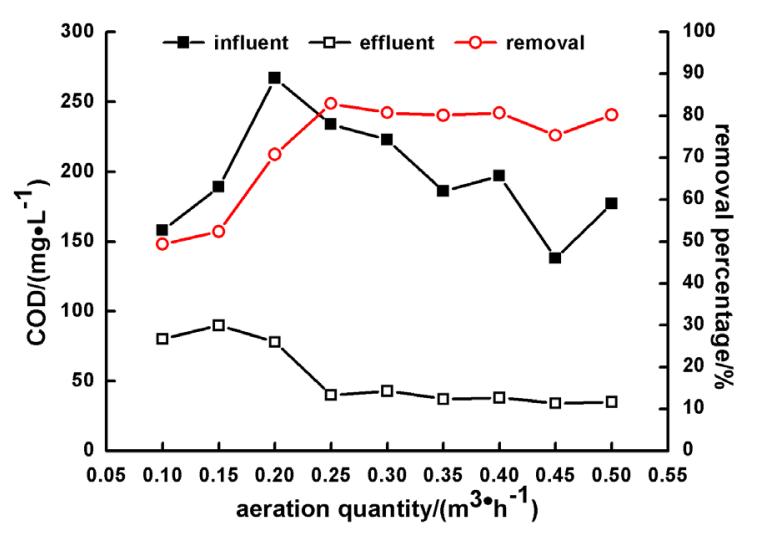

Fig. 3 Influence of aeration quantity on COD removal. determine the optimum aeration quantity. The SBMBR was first operated for $10 \mathrm{~d}$ with an aeration quantity of $5.6 \mathrm{~m}^{3} / \mathrm{m}^{3} \cdot \mathrm{h}$. Then the aeration quantity was gradually increased after every $2 \mathrm{~d}$ operation. The monitored COD removal percentage increased from $49.4 \%$ to $82.9 \%$ when increasing the aeration quantity from 5.6 to $13.9 \mathrm{~m}^{3} / \mathrm{m}^{3} \cdot \mathrm{h}$ (Fig. 3). As the aeration quantity continued to rise, there was no significant increase in the COD removal percentage, which remained at around $80 \%$ and the effluent COD value remained at $<50 \mathrm{mg} / \mathrm{L}$. Therefore, it is appropriate to keep the aeration quantity at the level of $13.9 \mathrm{~m}^{3} / \mathrm{m}^{3} \cdot \mathrm{h}$.

\subsection{Membrane fouling and cleaning}

To study the membrane fouling, the aeration quantity was kept at $13.9 \mathrm{~m}^{3} / \mathrm{m}^{3} \cdot \mathrm{h}$, and a new membrane was continuously used for $60 \mathrm{~d}$. During the experiment, the concentration of activated sludge remained at the level of 5000$6000 \mathrm{mg} / \mathrm{L}$. The variations of transmembrane pressure (TMP) and membrane flux are shown in Fig. 4a. The variations of TMP could be divided into three stages: 1-15 d, 15-30 $\mathrm{d}$ and 31-40 d. In the first stage, TMP increased slowly within the range of 6 to $14 \mathrm{kPa}$; in the second stage, TMP increased at a quicker pace, but maintained in the range of 14-30 kPa; in the third stage, TMP increased more rapidly compared with the second stage, from 32 to $50 \mathrm{kPa}$. When TMP increased to $50 \mathrm{kPa}$, a chemical reverse cleaning was conducted to the membrane. The rise of TMP was possible due to the gradually exacerbating membrane fouling. At the very outset, the filter cake layer had not yet fully formed on the membrane surface, so TMP increased slowly. In the second stage, some small particles caused the clogging of membrane pores, and stuck to the membrane surface to form a filter cake layer, accelerating the increase of TMP. In the third stage, the filter cake layer was pressed hard on the membrane surface and thus further sped up the rise of TMP. When the system was operated for $40 \mathrm{~d}$, the TMP approximated $50 \mathrm{kPa}$. At this moment, the system was carried out a chemical cleaning, after which the TMP returned back almost to the initial value.

For the membrane cleaning, hydrochloric acid $(\mathrm{HCl}$, $\mathrm{pH} \approx 2)$, sodium hydroxide $(\mathrm{NaOH}, \mathrm{pH} \approx 12)$ and sodium hypochlorite $(\mathrm{NaClO}, 1 \%)$ were used respectively and the results are shown in Fig. 4b. When $\mathrm{HCl}$ was used, the cleaning effect was the best. The membrane flux could be basically restored within $<20 \mathrm{~min}$. The cleaning effect was reduced by using $\mathrm{NaOH}$ as the cleaning agent while $\mathrm{NaClO}$ showed the poorest cleaning effect. Typically, the main membrane foulings are activated sludge, colloids and 


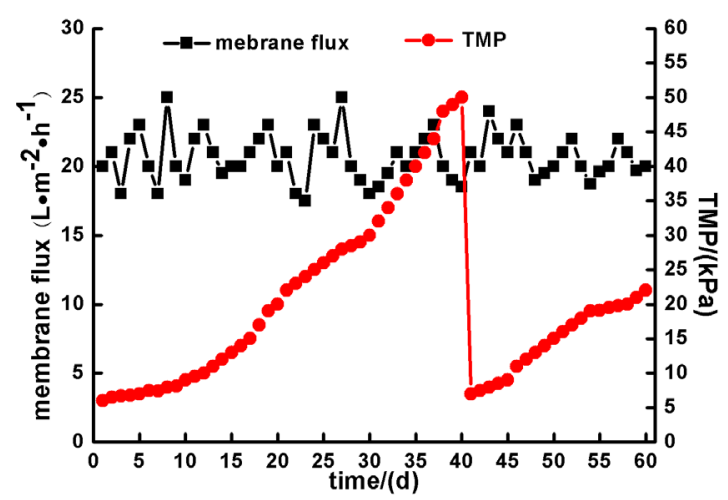

(a)

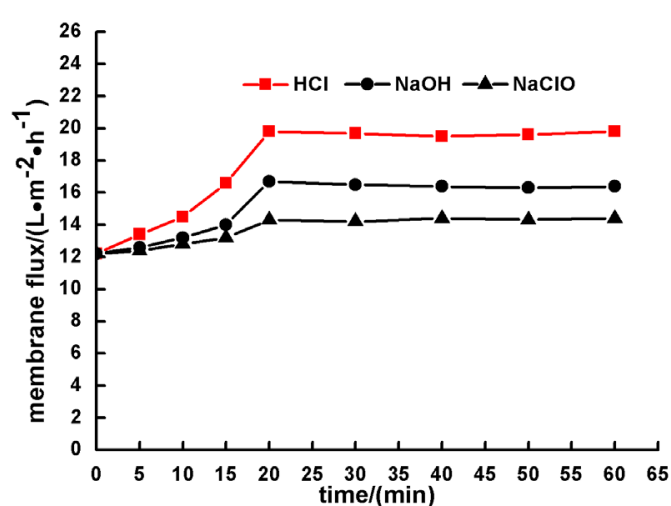

(b)

Fig. 4 Membrane fouling and cleaning: (a) variations of membrane flux and transmembrane pressure (TMP), and (b) effects of membrane cleaning with different agents.

inorganic solids. These substances stack on and foul the membrane surface under the influence of TMP and penetration of water flow. The inorganic solids are mainly calcium carbonates, which can be dissolved and removed by the acid cleaning agent [29]. Although organics, silica and biological foulings attached to the membrane surface are also easy to be cleaned under alkaline conditions, a relatively long time is needed to remove them from the membrane by the water erosion and air bubble friction. Moreover, since the alkali liquor cannot dissolve inorganic solids, it is unlikely to completely remove the membrane fouling. $\mathrm{NaClO}$ dilute solution has very good effects of removing microorganisms and proteins that stuck to membrane pores but has not very good effects of cleaning of other fouling.

\section{Conclusions}

The SBMBR showed a good treatment effect for the domestic wastewater treatment. When the average water flux on average remained at $20 \mathrm{~L} / \mathrm{h} \cdot \mathrm{m}^{2}$ and anaerobic and aerobic periods were $2 \mathrm{~h}$ and $3 \mathrm{~h}$, respectively, the effluent $\mathrm{COD}, \mathrm{NH}_{3}-\mathrm{N}, \mathrm{TN}$ and turbidity were below $50 \mathrm{mg} / \mathrm{L}$, $5 \mathrm{mg} / \mathrm{L}, 15 \mathrm{mg} / \mathrm{L}$ and 2.6 NTU, respectively. The chroma

\section{References}

[1] Fu, J., Yang, X., Chen, R., Luo, Y., Wu, C., Jia, H., Zhu, H. "Distributed treatment of domestic wastewater using an integrated equipment. Part-I. Pilot study on the treatment of domestic wastewater by sequencing batch biofilm reactor", Energy Education Science and Technology Part A-Energy Science and Research, 30, pp. 445-458, 2012.

[2] Asano, T., Burton, F. L., Leverenz, H. L., Tsuchihashi, R., Tchobanoglous, G. "Water reuse: Issue, technologies, and applications", McGRAW-HILL, New York, USA, 2007. removal percentage could reach the level of $96.9 \%$. The total number of bacteria in the effluent water remained basically at the level of $<1 \times 10^{3} \mathrm{cfu} / \mathrm{L}$, with the removal percentage at $>99.9 \%$. The aeration quantity had a certain degree of impact on the removal of COD. When the quantity was below $13.9 \mathrm{~m}^{3} / \mathrm{m}^{3} \cdot \mathrm{h}$, the COD removal percentage of the system declined as the aeration reduced. While when the quantity was at $>13.9 \mathrm{~m}^{3} / \mathrm{m}^{3} \cdot \mathrm{h}$, the COD removal was not significantly influenced by aeration quantity. Under the conditions of $20 \mathrm{~L} / \mathrm{h} \cdot \mathrm{m}^{2}$ of membrane flux and 5000-6000 mg/L of activated sludge, the TMP reached $50 \mathrm{kPa}$ after operating the SBMBR for $40 \mathrm{~d}$. After the chemical cleaning using $\mathrm{HCl}(\mathrm{pH} \approx 2)$, the membrane could be easily restored to the previous flux.

\section{Acknowledgement}

This work was supported by Major Science and Technology Program for Water Pollution Control and Treatment (2012ZX07206-002), Knowledge Innovation Program of Shenzhen (JCYJ20160526162154729), and POWERCHINA HUADONG Science and Technology Project (KY2016-02-04).

[3] Purnell, S., Ebdon, J., Buck, A., Tupper, M., Taylor, H. "Removal of phages and viral pathogens in a full-scale MBR: Implications for wastewater reuse and potable water", Water Research, 100, pp. $20-27,2016$.

https://doi.org/10.1016/j.watres.2016.05.013

[4] Norton-Brandão, D., Scherrenberg, S. M., Lier, J. B. V. "Reclamation of used urban waters for irrigation purposes-a review of treatment technologies", Journal of Environmental Management, 122C, pp. 85-98, 2013. https://doi.org/10.1016/j.jenvman.2013.03.012 
[5] Hai, F., Riley, T., Shawkat, S., Magram, S. F., Yamamoto, K. "Removal of pathogens by membrane bioreactors: A review of the mechanisms, influencing factors and reduction in chemical disinfectant dosing", Water, 6, pp. 3603-3630, 2014. https://doi.org/10.3390/w6123603

[6] Krzeminski, P., Iglesias-Obelleiro, A., Madebo, G., Garrido, J. M., van der Graaf, J. H. J. M., van Lier, J. B. "Impact of temperature on raw wastewater composition and activated sludge filterability in full-scale MBR systems for municipal sewage treatment", Journal of Membrane Science, 423-424, pp. 348-361, 2012.

https://doi.org/10.1016/j.memsci.2012.08.032

[7] Visvanathan, C., Aim, R. B., Parameshwaran, K. "Membrane separation bioreactors for wastewater treatment", Critical Reviews in Environmental Science and Technology, 30, pp. 1-48, 2000. https://doi.org/10.1080/10643380091184165

[8] Seo, G. T., Lee, T. S., Moon, B. H., Lim, J. H., Lee, K. S. "Two stage intermittent aeration membrane bioreactor for simultaneous organic, nitrogen and phosphorus removal", Water Science \& Technology, 41, pp. 217-225, 2000. [online] Available at: http://wst. iwaponline.com/content/41/10-11/217 [Accessed: 04 March 2018]

[9] Murakami, T., Usui, J., Takamura, K., Yoshikawa, T. "Application of immersed type membrane separation activated sludge process to municipal wastewater treatment", Water Science \& Technology, 41, pp. 295-301, 2000. [online] Available at: http://wst.iwaponline. com/content/41/10-11/295 [Accessed: 04 March 2018]

[10] Bouhbila, E. H., Aim, R. B., Buisson, H. "Fouling characterisation in membrane bioreactors", Seqaration and Purification Technology, 22-23, pp. 123-132, 2001. https://doi.org/10.1016/S1383-5866(00)00156-8

[11] Ng, A. N. L., Kim, A. S. "A mini-review of modeling studies on membrane bioreactor (MBR) treatment for municipal wastewaters", Desalination, 212, pp. 261-281, 2007.

https://doi.org/10.1016/j.desal.2006.10.013

[12] Ayesha R. D., Ergas, S. J. "Membrane bioreactor for cometabolism of trichloroethene air emissions", Journal of Environmental Engineering, 126, pp. 969-972, 2000. https://doi.org/10.1061/(ASCE)0733-9372(2000)126:10(969)

[13] Fenu, A., Guglielmi, G., Jimenez, J., Sperandio, M., Saroj, D., Lesjean, B., Brepols, C., Thoeye, C., Nopens, I. "Activated sludge model (ASM) based modelling of membrane bioreactor (MBR) processes: A critical review with special regard to MBR specificities", Water Research, 44, pp. 4272-4294, 2010.

https://doi.org/10.1016/j.watres.2010.06.007

[14] de la Torre, T., Lesjean, B., Drews, A., Kraume, M. "Monitoring of transparent exopolymer particles (TEP) in a membrane bioreactor (MBR) and correlation with other fouling indicators", Water Science \& Technology, 58, pp. 1903-1909, 2008. https://doi.org/10.2166/wst.2008.752

[15] Grelot, A., Machinal, C., Drouet, K., Tazi-Pain, A., Schrotter, J. C., Grasmick, A., Grinwis, S. "In the search of alternative cleaning solutions for MBR plants", Water Science \& Technology, 58, pp. 2041-2049, 2008.

https://doi.org/10.2166/wst.2008.759

[16] Radjenovic, J., Petrovic, M., Barcelo, D. "Fate and distribution of pharmaceuticals in wastewater and sewage sludge of the conventional activated sludge (CAS) and advanced membrane bioreactor (MBR) treatment", Water Research, 43, pp. 831-841, 2009. https://doi.org/10.1016/j.watres.2008.11.043
[17] McAdam, E. J., Judd, S. J. "A review of membrane bioreactor potential for nitrate removal from drinking water", Desalination, 196, pp. 135-148, 2006.

https://doi.org/10.1016/j.desal.2006.03.008

[18] Zhang, H., Xiao, J.; Cheng, Y., Liu, L., Zhang, X., Yang, F. "Comparison between a sequencing batch membrane bioreactor and a conventional membrane bioreactor", Process Biochemistry, 41, pp. 87-95, 2006.

https://doi.org/10.1016/j.procbio.2005.03.072

[19] State Environmental Protection Administration. "Determination methods for examination of water and wastewater", China Environmental Science Press, Beijing, China, 2002.

[20] Rice, E. W., Baird, R. B., Eaton, A. D. "Standard methods for the examination of water and wastewater", Water Environment Federation, Washington, DC, USA, 2005.

[21] Miller, D. J., Kasemset, S., Paul, D. R., Freeman, B. D. "Comparison of membrane fouling at constant flux and constant transmembrane pressure conditions", Journal of Membrane Science, 454, pp. 505-515, 2014.

https://doi.org/10.1016/j.memsci.2013.12.027

[22] Guo, J., Xia, S., Wang, R., Zhao, J. "Study on membrane fouling of submerged membrane bioreactor in treating bathing wastewater", Journal of Environmental Sciences, 20, pp. 1158-1167, 2008. https://doi.org/10.1016/S1001-0742(08)62204-4

[23] Luo, Y., Guo, W., Ngo, H. H., Nghiem, L. D., Hai, F. I., Zhang, J., Liang, S., Wang, X. C. "A review on the occurrence of micropollutants in the aquatic environment and their fate and removal during wastewater treatment", Science of the Total Environment, 473, pp. 619-641, 2014.

https://doi.org/10.1016/j.scitotenv.2013.12.065

[24] Wu, M., Zhu, R., Zhu, H., Dai, X., Yang, J. "Phosphorus removal and simultaneous sludge reduction in humus soil sequencing batch reactor treating domestic wastewater", Chemical Engineering Journal, 215-216, pp. 136-143, 2012.

https://doi.org/10.1016/j.cej.2012.11.066

[25] Lebrero, R., Gondim, A. C., Pérez, R., García-Encina, P. A., Muñoz, R. "Comparative assessment of a biofilter, a biotrickling filter and a hollow fiber membrane bioreactor for odor treatment in wastewater treatment plants", Water Research, 49, pp. 339-350, 2013. https://doi.org/10.1016/j.watres.2013.09.055

[26] Abegglen, C., Ospelt, M., Siegrist, H. "Biological nutrient removal in a small-scale mbr treating household wastewater", Water Research, 42, pp. 338-346, 2008. https://doi.org/10.1016/j.watres.2007.07.020

[27] Hirani, Z. M., DeCarolis, J. F., Adham, S. S., Jacangelo, J. G. "Peak flux performance and microbial removal by selected membrane bioreactor systems", Water Research, 44, pp. 2431-2440, 2010. https://doi.org/10.1016/j.watres.2010.01.003

[28] Meng, F., Yang, F., Shi, B., Zhang, H. "A comprehensive study on membrane fouling in submerged membrane bioreactors operated under different aeration intensities", Separation and Purification Technology, 59, pp. 91-100, 2008. https://doi.org/10.1016/j.seppur.2007.05.040

[29] Baker, R. W. "Membrane technology and applications", John Wiley \& Sons, Hoboken, NJ, USA, 2004. 